\title{
Economic benefit analysis of low-level high vacuum compaction method from the perspective of low carbon
}

\author{
Liangrong Yuan ${ }^{1}$, Menglan Song ${ }^{2}$ \\ Anhui Sanlian University, Hefei, 230601, China \\ ${ }^{1}$ Corresponding author \\ E-mail: ${ }^{1}$ seapie@163.com, ${ }^{2} 52474900 @ q q . c o m$
}

Received 6 March 2019; received in revised form 6 June 2019; accepted 30 June 2019 DOI https://doi.org/10.21595/jve.2019.20637

Check for updates

Copyright $(2019$ Liangrong Yuan, et al. This is an open access article distributed under the Creative Commons Attribution License, which permits unrestricted use, distribution, and reproduction in any medium, provided the original work is properly cited.

\begin{abstract}
In order to discuss the superiorities of High Vacuum Drubbing Means (HVDM) in soft foundation treatment of roads, this paper takes the soft foundation treatment project of Wucheng Road in Wuwei County of Wanjiang City Belt in China as an example. By comparing and analyzing the economic benefit differences between HVDM method and traditional powder injection pile method in soft soil foundation treatment, the following conclusions are drawn: Low-level high-vacuum compaction method soft base processing method is better than traditional powder-jet pile method in soft foundation treatment. The method can better reduce the consumption of raw materials such as cement and stone, avoid the pollution of the social environment caused by cement production, shorten the construction period by about $50 \%$ and save the direct labor cost. Compared with the traditional powder-sprayed pile method, total cost of the project can be saved by more than $30 \%$ and the construction quality is controllable. The construction process is green and its social and economic benefits are remarkable.
\end{abstract}

Keywords: High vacuum drubbing means (HVDM), economic benefits, soft foundation treatment, cost analysis.

\section{Introduction}

With the rapid development of China's social economy, road construction and bridge construction have played an important role in promoting regional economic development and will become the norm state of social and economic construction. However, there are some shortcomings in traditional road soft foundation treatment methods, such as long construction period, high cost, impacting natural landscape, destroying ecological environment. In addition, it will directly or indirectly cause air, soil and water pollution and lead to various geological disasters. Obviously, this traditional road soft foundation treatment method with high pollution, high cost and high risk needs to be improved and innovated urgently.

Low-level high vacuum compaction method is a new technology for fast consolidation of soft soil foundation. It mainly achieves the purpose of reducing soil water content, improving soil compactness and bearing capacity, reducing post-construction settlement and differential settlement of foundation through several times of high vacuum differential pressure drainage and several times of suitable variable energy compaction. This method combines the two processes of rapid high vacuum drainage and densification organically and circulates many times, forming the unique mechanism of low-level high vacuum densification. The low-level high vacuum compaction method is suitable for foundations with large natural water content, small compression modulus and low load carrying capacity, such as deep silt layer, silty soil, soft filling soil, miscellaneous filling and other high compressibility soft soil and so on. The application of low-level high vacuum compaction method [1-13] can not only reduce the environmental pollution caused by cement slurry and dust generated by traditional construction methods, but also reduce the amount of cement used, thereby reducing the large amount of industrial wastewater and exhaust gas discharged during the exploitation and production of raw cement resources to achieve the purpose of protecting water resources and ecological environment. 
Low-level and high-vacuum compaction is a new construction method. Li Jingpei and Ma Yuan [14] selected some sections of Wujiang Renmin Road as examples to analyze the reinforcement effect of high-vacuum compaction method; Huang Xiaozhi [15] discussed the key points and methods of supervision and control of soft foundation treatment by low-level and high-vacuum stratified compaction method; Dubey R. S. [16] studied the construction vacuum dewatering method of rigid pavement. At present, researchers at home and abroad mainly focus on introducing the principle, improving the construction method, comparing the reinforcement effect with traditional construction method and discussing its construction technology. However, there is a lack of analysis and research on the construction cost, economic benefits and social benefits of low-level high vacuum compaction method. Taking Wucheng Road soft foundation treatment project in Wuwei County of Wanjiang City Belt as an example, the economic and social benefits of low-level high vacuum compaction method and traditional dry jet pile method in dealing with bad subgrade are studied and analysed in this paper.

\section{Economic benefit analysis}

\subsection{The basis of calculating standards}

The calculation criteria are implemented according to relevant policies and documents such as Anhui Municipal Engineering Budget Estimate Quota, as follows:

- National Unified Municipal Engineering Budget Quota Valuation Table of Anhui Province (2000);

- The engineering rate standard refers to "Anhui Municipal Engineering Cost Quota" (2000);

- The unit price of quota labor fee shall be executed in accordance with No. 16 of Construction Cost Management General Station of Anhui Province (2013);

- Taxes for construction projects are calculated on the basis of No. 26 of Construction Cost Management General Station of Anhui Province (2011);

- Prices of materials and equipment are included according to local market inquiries;

- Relevant documents promulgated by Wuhu Urban and Rural Construction Committee and Construction Cost Management Station.

\subsection{Direct cost of DJM pile method}

Powder-jet pile method [17-19] uses powder solidifying agent to mix soft foundation. Using cement, lime and other raw materials as the main solidifying agent, soft soil and solidifying agent (slurry and powder) are forced to mix in situ by special mixing machine, and a series of physical and chemical reactions between solidifying agent and soft soil are used to make soft soil into a foundation of high quality with integrity, water stability and certain strength.

\subsubsection{Quantities}

Wuwei County Wucheng Road Soft Foundation Project is about $1100 \mathrm{~m}$ long, $40 \mathrm{~m}$ wide and $44,000 \mathrm{~m}^{2}$ treated area. According to the design scheme, the design height of the top surface of the roadbed and the calculation of the road plane design plan, 43442 powder-sprayed piles are required for the motor lane, non-motor lane and sidewalk of this section. And the pile length is about $370593.2 \mathrm{~m}$, the cleaning surface is $116958.697 \mathrm{~m}^{3}$, while the filling volume is $1152.592 \mathrm{~m}^{3}$, of which about $77202.564 \mathrm{~m}^{3}$ is hill-skin stone backfill, about $33284.694 \mathrm{~m}^{3}$ is graded gravel, and the plain earth backfill and two-way fiberglass geogrid is $4515.334 \mathrm{~m}^{3}$ and $43560 \mathrm{~m}^{2}$ respectively. Fig. 1 shows the cross-sectional plan of foundation treatment in the Eighth Road Standard Section. The boundary lines of foundation treatment are $2 \mathrm{~m}$ out of the road red line and the foundation treatment width of the standard section is $44 \mathrm{~m}$. The boundary lines of foundation treatment in the non-standard section are also controlled according to the above principles. 


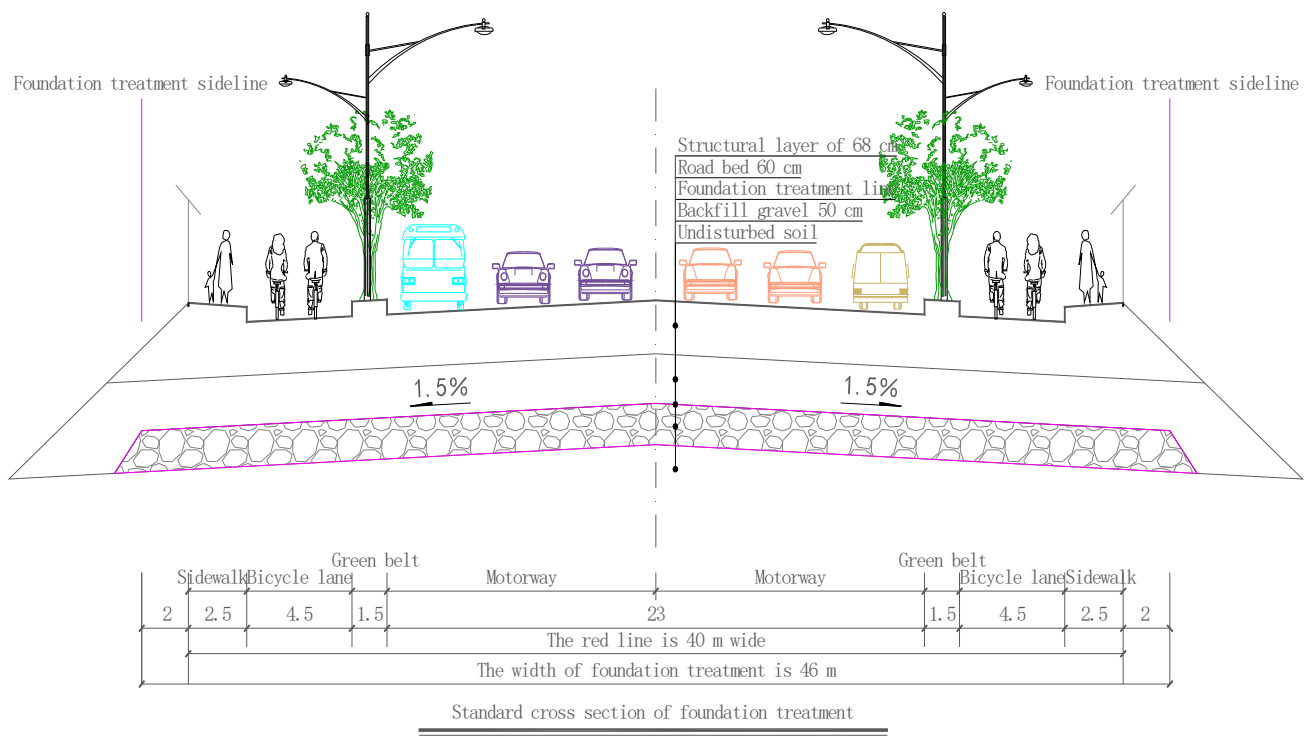

Fig. 1. Planning standard cross-sectional map of foundation treatment of eighth road sign (dimensions in meters except indicated)

\subsubsection{Project direct cost}

According to the above calculation criteria, it can be seen that DJM pile $(d=50 \mathrm{~cm}$, cement content $60 \mathrm{~kg} / \mathrm{m}$ ) is $55 \mathrm{yuan} / \mathrm{m}$, Hill pebble backfilling is $89.7 \mathrm{yuan} / \mathrm{m}^{3}$, two-way glass fiber geogrid is 15.87 yuan $/ \mathrm{m}^{2}$, graded gravel backfilling is 134.55 yuan $/ \mathrm{m}^{3}$, plain soil backfilling is 31.45 yuan $/ \mathrm{m}^{3}$, surface cleaning is $26.85 \mathrm{yuan} / \mathrm{m}^{3}$, the distance between abandoned party and debit party is $5 \mathrm{~km}$. The preliminary design budget for the treatment of soft foundation by dry jet grouting pile in Wucheng Road is shown in Table 1.

Table 1. Preliminary design budget for soft ground treatment of Wucheng road (DJM pile method)

\begin{tabular}{|c|c|c|c|c|c|c|}
\hline $\begin{array}{l}\text { Serial } \\
\text { number }\end{array}$ & Entry name & Company & Quantities & $\begin{array}{l}\text { Unit } \\
\text { price } \\
\text { (yuan) }\end{array}$ & $\begin{array}{c}\text { Total } \\
(10,000 \\
\text { yuan }) \\
\end{array}$ & Remarks \\
\hline 1 & $\begin{array}{l}\text { Surface } \\
\text { cleaning }\end{array}$ & $\mathrm{m}^{3}$ & 116958.70 & 26.85 & 314.03 & $\begin{array}{l}\text { Give up } 5 \mathrm{~km} \text { on the } \\
\text { outside }\end{array}$ \\
\hline 2 & $\begin{array}{c}d=50 \mathrm{~cm} \\
\text { Powder jet pile }\end{array}$ & $\mathrm{m}$ & 370593.20 & 55.00 & 2038.26 & $\begin{array}{c}\text { Cement content is } \\
60 \mathrm{~kg} / \mathrm{m}\end{array}$ \\
\hline 3 & $\begin{array}{c}\text { Graded } \\
\text { macadam } \\
\text { backfilling }\end{array}$ & $\mathrm{m}^{3}$ & 33284.69 & 134.55 & 447.85 & $\begin{array}{c}\text { Pile Top } \\
\text { Cushion/Leveling } \\
\text { Layer }\end{array}$ \\
\hline 4 & $\begin{array}{c}\text { Bidirectional } \\
\text { fiberglass } \\
\text { geogrid } \\
\end{array}$ & $\mathrm{m}^{2}$ & 43560.00 & 15.87 & 69.13 & Leveling layer \\
\hline 5 & $\begin{array}{l}\text { Backfilling of } \\
\text { hillside stones }\end{array}$ & $\mathrm{m}^{3}$ & 77202.56 & 89.70 & 692.51 & \\
\hline 6 & $\begin{array}{l}\text { Prime soil } \\
\text { backfill }\end{array}$ & $\mathrm{m}^{3}$ & 4515.33 & 31.45 & 14.20 & $\begin{array}{l}\text { Excavation, } 5 \mathrm{~km} \\
\text { borrowing and } \\
\text { compaction }\end{array}$ \\
\hline 7 & Total & & & & 3575.98 & \\
\hline
\end{tabular}

The total direct cost of soft foundation treatment with DJM piles is 35.7598 million yuan, and the unit cost is 35.7598 million yuan $/(1,100 \mathrm{~m} \times 40 \mathrm{~m} / 10,000)=812.72 \mathrm{yuan} / \mathrm{m}^{2}$. 


\subsection{Direct cost of low and high vacuum densification}

\subsubsection{Quantities}

According to the scheme and the calculation of the design height of the top surface of the roadbed, the engineering quantities are as follows: the cleaning surface is $66107.8 \mathrm{~m}^{3}$; the backfilling volume of hilly stones is about $36059 \mathrm{~m}^{3}$; the plastic drainage board is $417347 \mathrm{~m}$ without portal frame bag sand rig; the geotextile is $66107.8 \mathrm{~m}^{2}$; the vacuum film is $135.6 \mathrm{~m}^{2}$; the full ramming energy of dynamic compaction soil foundation is less than $120 \mathrm{kN} \cdot \mathrm{m}$, ramming once, and the soft foundation area of repeated ramming hammer at each position is $60098 \mathrm{~m}^{2}$; The tamping energy of base point is less than $2000 \mathrm{kN} \cdot \mathrm{m}$, the number of tamping points per $100 \mathrm{~m}^{2}$ is less than 12, and the soft foundation area is $18094 \mathrm{~m}^{2}$ with repeated tamping times less than 4 times at each tamping point.

Table 2. Preliminary design budget for soft subgrade treatment of Wucheng road (low-level high vacuum densification method)

\begin{tabular}{|c|c|c|c|c|c|c|}
\hline $\begin{array}{c}\text { Serial } \\
\text { number }\end{array}$ & Entry name & Company & Quantities & $\begin{array}{c}\text { Unit Price } \\
\text { (yuan) }\end{array}$ & $\begin{array}{c}\text { Total }(10,000 \\
\text { yuan })\end{array}$ & Remarks \\
\hline 1 & Surface cleaning & $\mathrm{m}^{3}$ & 66107.80 & 26.85 & 177.50 & $\begin{array}{c}\text { Give up } 5 \mathrm{~km} \text { on the } \\
\text { outside }\end{array}$ \\
\hline 2 & Sand floor & $\mathrm{m}^{2}$ & 60098.00 & 63.93 & 384.21 & Thick $20 \mathrm{~cm}$ \\
\hline 3 & Dig trenches & $\mathrm{m}^{3}$ & 4620.00 & 5.66 & 2.61 & \\
\hline 4 & Dig earth & $\mathrm{m}^{3}$ & 9240.00 & 3.95 & 3.65 & \\
\hline 5 & $\begin{array}{c}\text { Plastic drainage } \\
\text { board }\end{array}$ & $\mathrm{m}$ & 417347.00 & 11.48 & 479.11 & $\begin{array}{l}\text { Sand-filling Machine } \\
\text { without Portal Frame }\end{array}$ \\
\hline 6 & $\begin{array}{l}\text { Construction } \\
\text { precipitation }\end{array}$ & $\mathrm{m}^{2}$ & 60098.00 & 7.70 & 46.28 & Light well point \\
\hline 7 & Vacuum membrane & $\mathrm{m}^{2}$ & 132215.60 & 8.10 & 107.09 & \\
\hline 8 & Geotextiles & $\mathrm{m}^{2}$ & 66107.80 & 8.10 & 53.55 & \\
\hline 9 & $\begin{array}{l}\text { Point tamping of } \\
\text { dynamic compaction } \\
\text { soil foundation }\end{array}$ & $\mathrm{m}^{2}$ & 180294.00 & 21.50 & 387.63 & $\begin{array}{l}\text { The tamping energy is } \\
\text { less than } 2000 \mathrm{kN} . \mathrm{m} \text {, } \\
\text { the number of tamping } \\
\text { points per } 100 \mathrm{~m} 2 \text { is } \\
\text { less than } 12 \text { points, and } \\
\text { the number of repeated } \\
\text { tamping times per point } \\
\text { is less than } 4 \text { times. }\end{array}$ \\
\hline 10 & $\begin{array}{l}\text { Full compaction of } \\
\text { dynamic compaction } \\
\text { soil foundation }\end{array}$ & $\mathrm{m}^{2}$ & 60098.00 & 9.26 & 55.65 & $\begin{array}{c}\text { Tamping energy } \\
<1200 \mathrm{kN} . \mathrm{m} \text {, tamping } \\
\text { once, tamping twice } \\
\text { per tamping point }\end{array}$ \\
\hline 11 & $\begin{array}{l}\text { Vacuum preloading } \\
\text { period }\end{array}$ & $\mathrm{m}^{2}$ & 60098.00 & 75.00 & 450.74 & 2 months \\
\hline 12 & $\begin{array}{l}\text { Backfilling of } \\
\text { hillside stones }\end{array}$ & $\mathrm{m}^{3}$ & 36059.00 & 89.70 & 323.45 & \\
\hline & Total & & & & 2471.47 & \\
\hline
\end{tabular}

\subsubsection{Project direct cost}

The direct cost of the low-level high-vacuum compaction method consists of cleaning the road surface, strong tamp, precipitation, etc. The calculation standard is based on the above.

According to the above calculation criteria, plastic drainage plate without portal frame bag sand rig 11.48 yuan $/ \mathrm{m}$, geotextile 8.10 yuan $/ \mathrm{m}^{2}$, vacuum film 8.10 yuan $/ \mathrm{m}^{2}$, dynamic compaction soil base full compaction 9.26 yuan $/ \mathrm{m}^{2}$, dynamic compaction soil base point compaction 21.5 yuan $/ \mathrm{m}^{2}$, light well point construction dewatering 7.7 yuan $/ \mathrm{m}^{2}$; sand bottom $63.93 \mathrm{yuan} / \mathrm{m}^{2}$; 
vacuum preloading period ( 2 months) $75 \mathrm{yuan} / \mathrm{m}^{2}$. The preliminary design budget of high vacuum compaction treatment for soft foundation of Wucheng Road is shown in Table 2.

The total direct cost of soft foundation treatment by low-level and high vacuum compaction method is 24.717 million yuan, and the unit cost is 24.7147 million yuan $/(1,100 \mathrm{~m} \times 40 \mathrm{~m} / 10,000)$ $=561.7$ yuan $/ \mathrm{m}^{2}$.

\subsection{Contrastive analysis of economic benefits between low-level high vacuum densification method and powder jet pile method}

\subsubsection{Direct cost comparison}

Taking Wucheng Road soft foundation treatment project in Wuwei County of Wanjiang City Belt as an example (1100 m long, $40 \mathrm{~m}$ wide and 44,000 $\mathrm{m}^{2}$ engineering volume), high vacuum compaction soft foundation treatment method is adopted instead of traditional dry jet pile method. The direct cost comparison analysis results are shown in Figure 2.

Fig. 2 shows that the direct cost per unit of DJM pile soft foundation treatment method is 812.72 yuan $/ \mathrm{m}^{2}$, while the corresponding part of low-level high vacuum compaction method is 561.70 yuan $/ \mathrm{m}^{2}$. Compared with the traditional construction method, the unit direct cost of the low-level high vacuum compaction method is reduced by 251.03 yuan $/ \mathrm{m}^{2}$, and the direct cost of the project is saved by $30.89 \%$. That is to say, if the case engineering uses the low-level high vacuum compaction method instead of the powder jet mixing pile to treat the soft foundation, the project will save 11.4451 million yuan in direct cost.

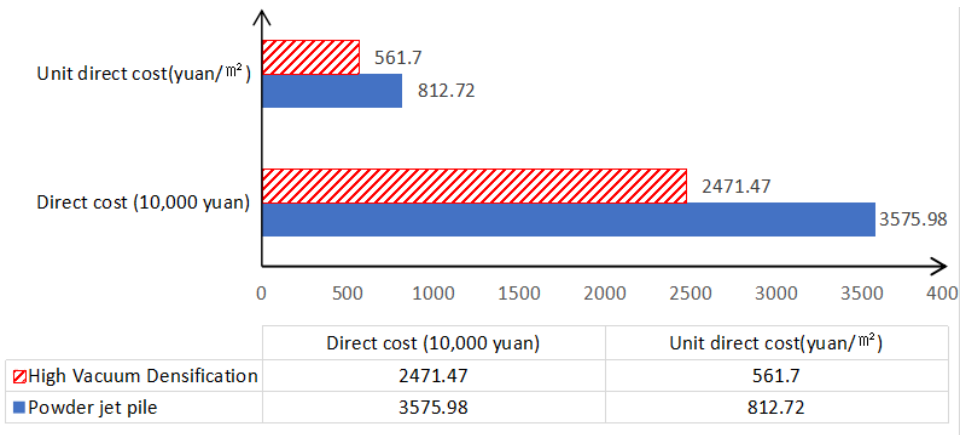

$\square$ High Vacuum Densification $\square$ Powder jet pile

Fig. 2. Direct cost comparison of powder-jet pile method and low-level high vacuum compaction method

The low-level and high vacuum compaction method has replaced the traditional method to deal with the bad roadbed. It has been used in the Yangxiang Road Project of Wuwei County in Anhui Province, the Eighth Road Project of Wuhu City Planning, the Second Phase Project of Jiangbei Industrial Concentration Area in Anhui Province, the Second Phase Extension Project of Jiangbei Industrial Concentration Area in Anhui Province, the Third Phase Project of Jiangbei Industrial Concentration Area in Anhui Province and Jiangnan Industrial Concentration Area in Anhui Province. It has been successfully applied in at least 6 projects. The basic situation of engineering application is shown in Table 3.

From Table 3, it can be seen that six soft foundation projects, such as Yangxiang Road Project in Wuwei County, Wanjiang City, Anhui Province, have a treatment area of 9717.11 million $\mathrm{m}^{2}$. The project cost $[20,21]$ of powder-jet pile method and low-level high vacuum compaction method are 789 million yuan and 545 million yuan respectively. By replacing the traditional method with the low-level high vacuum tamping method, only the above six engineering applications can save 244 million yuan of direct cost, with extremely significant economic benefits. According to the statistics bulletin of the Ministry of Housing and Urban-Rural 
Construction in 2016, as shown in Fig. 3, the total length of roads has increased by 20.771 million kilometers and the total area of roads has increased by 39.68 billion square meters in recent years.

Table 3. Basic situation of application of low-level high vacuum compaction soft foundation treatment project in Anhui

\begin{tabular}{|c|c|c|c|c|c|c|c|}
\hline $\begin{array}{c}\text { Serial } \\
\text { number }\end{array}$ & Engineering name & $\begin{array}{c}\text { Length } \\
(\mathrm{m})\end{array}$ & $\begin{array}{c}\text { Width } \\
(\mathrm{m})\end{array}$ & $\begin{array}{c}\text { Engineering } \\
\text { area } \\
\left(10,000 \mathrm{~m}^{2}\right)\end{array}$ & $\begin{array}{c}\text { Powder jet } \\
\text { pile method } \\
(10000 \text { yuan })\end{array}$ & $\begin{array}{c}\text { Low-level high } \\
\text { vacuum } \\
\text { densification } \\
\text { method } \\
(10,000 \text { yuan })\end{array}$ & $\begin{array}{c}\text { Cost } \\
\text { savings } \\
(10,000 \\
\text { yuan })\end{array}$ \\
\hline 1 & $\begin{array}{c}\text { Yangxiang Road Project } \\
\text { of Wuwei County South } \\
\text { New Town }\end{array}$ & 1986.7 & 36 & 7.15212 & 5812.69 & 4017.33 & 1795.36 \\
\hline 2 & $\begin{array}{c}\text { Planning of the Eighth } \\
\text { Road Project in Wuhu } \\
\text { City }\end{array}$ & 4641.353 & 44 & 20.4219 & 16597.38 & 11470.96 & 5126.42 \\
\hline 3 & $\begin{array}{c}\text { Phase II of Jiangbei } \\
\text { Industrial Concentration } \\
\text { Zone in Anhui } \\
\text { Province: Hehe Road, } \\
\text { Heping Road and } \\
\text { Wanjiang Avenue }\end{array}$ & 3340 & 46 & 15.3640 & 12486.67 & 8629.92 & 3856.75 \\
\hline $\begin{array}{c}\text { Second Extension } \\
\text { Section of Jiangbei } \\
\text { Industrial Concentration } \\
\text { Zone in Anhui } \\
\text { Province: Heyue Road, } \\
\text { He }\end{array}$ & 3799 & 38 & 14.4362 & 11732.63 & 8108.78 & 3623.85 \\
\hline 5 & $\begin{array}{c}\text { Three Phases of } \\
\text { Jiangbei Industrial } \\
\text { Concentration Zone in } \\
\text { Anhui Province: } \\
\text { Changhe Road, Xinshen } \\
\text { Road, Xinxing Road } \\
\text { and Harmony Road }\end{array}$ \\
$\begin{array}{c}\text { Jiangnan Industrial } \\
\text { Concentration Zone in } \\
\text { Anhui Province: } \\
\text { Chizhou Avenue and } \\
\text { Yingbin Avenue }\end{array}$ & 2338 & 32 & 7.4816 & 6080.47 & 4202.40 & 1878.07 \\
\hline Total & 76 & 32.3152 & 26263.29 & 18151.37 & 8111.92 \\
\hline & & & & & & \\
\hline
\end{tabular}

From the statistical chart, we can see that the road area increases linearly every year. The data are linearly fitted by Excel. The result shows that the linear relationship between the road area and the year is $y=38057 x-7596.7$, that is, the average additional road area is 380570 million square meters per year. The results are shown in Fig. 4.

The difference of direct cost between the two methods is 251.03 yuan $/ \mathrm{m}^{2}\left(812.72 \mathrm{yuan} / \mathrm{m}^{2}\right.$ 561.7 yuan $/ \mathrm{m}^{2}$ ). Assuming that $10 \%$ of the new roads are treated by low-level and high vacuum compaction instead of traditional methods, the average annual investment will be saved by 388.1 billion $\mathrm{m}^{2} \times 25.103$ billion yuan $/ \mathrm{m}^{2}=9.564$ billion yuan, which is about $380.57 \times 10 \%=0.3805 .7$ billion $\mathrm{m}^{2}$ taking 0.38 billion $\mathrm{m}^{2}$. 


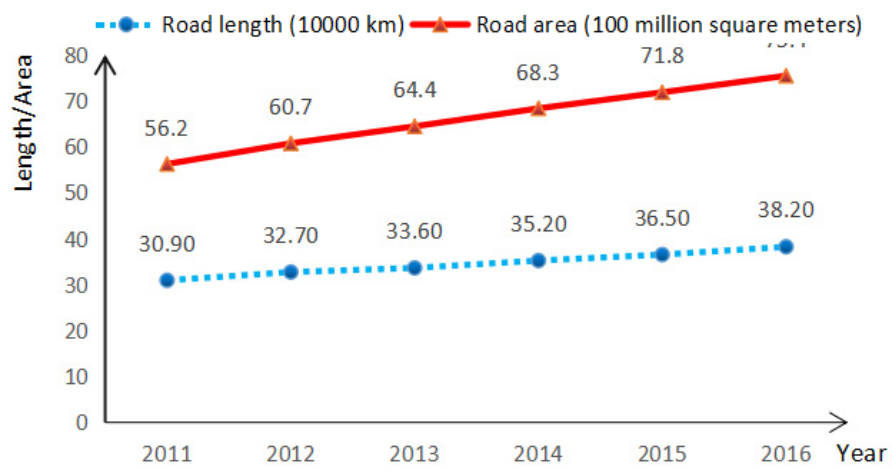

Fig. 3. Statistical map of urban road construction by ministry of construction in 2016

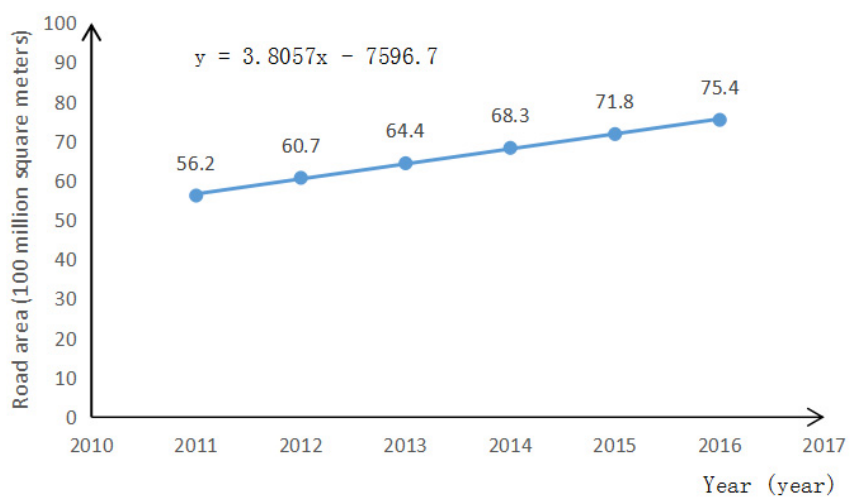

Fig. 4. Linear fitting map of urban road area for urban and rural construction of the ministry of construction in 2016

\subsubsection{Contrast of environmental protection benefits}

According to the introduction of China Academy of Environmental Sciences and China Cement Association, the cement industry is a key polluting industry, and the problems of resource consumption and ecological destruction are prominent. Carbon emission in cement production is second only to that in electric power industry. Particulate matter emission accounts for 20-30\% of the national particulate matter emission, and sulfur dioxide emission accounts for $5-6 \%$ of the national emissions. Fluorite is added to some shaft kilns to reduce burning heat consumption, and fluorine pollution in surrounding areas will also be caused.

According to relevant information, about $110 \mathrm{kWh}$ of electricity is needed for every ton of cement production. Electric power consumption in cement production can produce indirect $\mathrm{CO} 2$ emissions. According to the data released by the competent national authorities, the indirect $\mathrm{CO} 2$ emissions from electric power consumption in cement production are about $728 \mathrm{~kg} / \mathrm{t}$.

The cement consumption per square meter for soft foundation treatment by dry jet pile method is $505 \mathrm{~kg}$, or 0.505 tons. The electricity price of cement industry is generally 0.8 yuan $/ \mathrm{kWh}$, the charge of $\mathrm{CO} 2$ emission is 60 yuan/ton, and the standard coal is 400 yuan/ton. Thus the energy consumption per square meter is 89.73 yuan $(110 \times 0.8+0.728 \times 60+0.115 \times 400) \times 0.505$ tons $/ \mathrm{m}^{2}$.

It can be seen that the promotion of low-level high vacuum densification method will greatly reduce the consumption of natural ore and fuel, significantly reduce the intensity of greenhouse gas emissions per unit project, while saving a large number of comprehensive environmental protection treatment costs, resulting in considerable environmental benefits. The environmental benefits of the above six soft foundation projects are shown in Table 4.

1) Low-level high vacuum compaction method has been successfully applied in at least six 
projects, such as Yangxiang Road Project in Wuwei County, Wanjiang City Belt, Anhui Province, with an area of 9717.11 million $\mathrm{m}^{2}$ and an additional environmental benefit of 87.191 million yuan (9717.11 million $\mathrm{m}^{2} \times 89.73$ yuan $/ \mathrm{m}^{2}$ ).

2) According to the statistical bulletin of the Ministry of Housing and Urban-Rural Construction on urban-rural construction, a linear fitting is made. It can be seen that in recent years, about 381 million $\mathrm{m}^{2}$ of new road area has been added every year. Assuming that $10 \%$ of the new roads in China need foundation treatment every year, the average annual environmental benefit will be 344563.2 billion yuan ( 381 million $\mathrm{m}^{2} \times 10 \% \times 89.73$ yuan $/ \mathrm{m}^{2}$ ).

Table 4. Environmental benefits of application of low-level high vacuum densification soft foundation treatment project in Anhui province

\begin{tabular}{|c|c|c|c|c|c|c|}
\hline \multirow{2}{*}{$\begin{array}{l}\text { Serial } \\
\text { number }\end{array}$} & \multirow[t]{2}{*}{ Engineering name } & $\begin{array}{c}\text { Engineering } \\
\text { area }\end{array}$ & $\begin{array}{l}\text { Powder } \\
\text { jet pile } \\
\text { method }\end{array}$ & $\begin{array}{c}\text { Low vacuum } \\
\text { densification } \\
\text { method }\end{array}$ & $\begin{array}{l}\text { Direct } \\
\text { benefit }\end{array}$ & $\begin{array}{l}\text { Environmental } \\
\text { benefits }\end{array}$ \\
\hline & & $\left(\mathrm{m}^{2}\right)$ & $\begin{array}{c}(10000 \\
\text { yuan })\end{array}$ & (10000 yuan) & $\begin{array}{c}(10000 \\
\text { yuan })\end{array}$ & (10000 yuan) \\
\hline 1 & $\begin{array}{c}\text { Yangxiang Road Project of } \\
\text { Wuwei County South New } \\
\text { Town } \\
\end{array}$ & 71521.2 & 5812.69 & 4017.33 & 1795.36 & 641.76 \\
\hline 2 & $\begin{array}{l}\text { Planning of the Eighth Road } \\
\text { Project in Wuhu City }\end{array}$ & 204219.53 & 16597.38 & 11470.96 & 5126.42 & 1832.46 \\
\hline 3 & $\begin{array}{c}\text { Phase II of Jiangbei } \\
\text { Industrial Concentration } \\
\text { Zone in Anhui Province: } \\
\text { Hehe Road, Heping Road } \\
\text { and Wanjiang Avenue }\end{array}$ & 153640 & 12486.67 & 8629.92 & 3856.75 & 1378.61 \\
\hline 4 & $\begin{array}{c}\text { Second Extension Section of } \\
\text { Jiangbei Industrial } \\
\text { Concentration Zone in Anhui } \\
\text { Province: Heyue Road, } \\
\text { Heyue Road and Changhen } \\
\text { Road }\end{array}$ & 144362 & 11732.63 & 8108.78 & 3623.85 & 1295.36 \\
\hline 5 & $\begin{array}{l}\text { Three Phases of Jiangbei } \\
\text { Industrial Concentration } \\
\text { Zone in Anhui Province: } \\
\text { Changhe Road, Xinshen } \\
\text { Road, Xinxing Road and } \\
\text { Harmony Road } \\
\end{array}$ & 74816 & 6080.47 & 4202.4 & 1878.07 & 671.32 \\
\hline 6 & $\begin{array}{c}\text { Jiangnan Industrial } \\
\text { Concentration Zone in Anhui } \\
\text { Province: Chizhou Avenue } \\
\text { and Yingbin Avenue }\end{array}$ & 323152 & 26263.29 & 18151.37 & 8111.92 & 2899.64 \\
\hline & Total & 971710.73 & 78973.13 & 54580.76 & 24392.37 & 8719.16 \\
\hline
\end{tabular}

\section{Social benefit analysis}

\subsection{Conform to national policy, cater to development and build a resource-saving country}

"Entering the ecological civilization and building a beautiful China" is an important part of the Chinese nation's realization of the Chinese dream. In accordance with the concept of respecting, conforming to and protecting nature, China will implement the basic national policy of saving resources and protecting the environment, and support and encourage the conservation and comprehensive utilization of resources. Therefore, it is in line with the requirements of the development of the times to actively promote the new technology of low-level and high-vacuum compaction and the new technology of soft foundation treatment. 


\subsection{Reducing pollution and beautifying environment and constructing an environment- friendly society}

Ecological civilization emphasizes respecting and protecting nature, so as to realize sustainable development of economy and society. Using low-level High Vacuum Densification Method to treat soft foundation can not only save natural resources for municipal road construction, but also effectively reduce harmful gas and water pollution from cement production. Moreover, it can reduce the pollution caused by dust, enhance people's awareness of environmental protection and energy conservation, and promote economic growth and coordinated development of environmental protection.

\section{Conclusions}

In this paper, the low-level high vacuum compaction method is used to replace the traditional powder-jet pile method in the treatment of bad subgrade. The economic and social benefits of the two methods are compared and analyzed. It is found that the economic and social benefits of the low-level high vacuum compaction method in the treatment of soft subgrade are significantly improved.

1) Low-level and high vacuum compaction soft foundation treatment method is a new technology for rapid consolidation of soft soil foundation, which has obvious advantages: firstly, reducing the consumption of raw materials such as cement and stone; secondly, avoiding environmental pollution in cement production; and thirdly, saving about $50 \%$ of the construction time, controllable quality as well as green and environmental friendly construction process compared with traditional construction methods.

2) The research results have been successfully applied to six soft foundation projects such as Yangxiang Road Project in Wuwei County, Wanjiang City Belt, Anhui Province. The treatment area of the project is 9717.11 million $\mathrm{m}^{2}$. The construction cost of powder-jet pile method and low-level high vacuum compaction method is 789 million yuan and 545 million yuan respectively. By replacing the traditional method with the low and high vacuum tamping method, only the above six engineering applications can generate direct economic benefits of 244 million yuan, environmental protection benefits of 87 million yuan, thus the economic benefits and social benefits are remarkable.

3) According to the statistics bulletin of urban and rural construction of the Ministry of Housing and Urban-Rural Construction, in recent years, an average area of 381 million $\mathrm{m}^{2}$ of new roads has been added every year. If $10 ; '$ \% of new roads use low-level high vacuum compaction method instead of traditional construction method for foundation treatment, the country can save an average of 9.564 billion yuan annually, and create better environmental benefits.

In a word, the application of low-level and high vacuum densification method has achieved remarkable results in saving mine resources, reducing environmental pollution and improving the economic and social benefits of the project, which is worth popularizing.

\section{Acknowledgements}

This research work was funded by the Research Fund of Humanities and Social Sciences Key Project of Anhui Sanlian University (SKZD2019001) and Anhui Provincial Quality Project Subsidy Project (2018JXTD057). The financial support is gratefully acknowledged.

\section{References}

[1] Gu J. M., Qian J. A Comparative analysis of reinforcement effect of three soft foundation treatment methods. Modern Transportation Technology, Vol. 14, Issue 2, 2017, p. 11-15.

[2] Cheng Y. Q., Zhang Y. J. The soft soil subgrade treatment high vacuum of method and application research. Water Resources Development and Management, Vol. 10, 2012, p. 13-15. 
[3] Gao Y. B., Shen Y., Shi Long X.-U., et al. Laboratory tests on saturated hydraulic fill sandy soil by high vacuum densification method. Journal of Hohai University, Vol. 37, Issue 1, 2009, p. 86-90.

[4] Teng S. K., Wang J. J., Shi Long X.-U., et al. Test of hydraulic fly ash fill by high vacuum densification method. Port and Waterway Engineering, 2004.

[5] Yuan Haiping, Han Zhiyong, Shi Xianzeng, et al. Study on acceleration effect of High Vacuum Densification on soft soil roadbed in Wanjiang. Subgrade Engineering, Vol. 5, 2015, p. 17-22.

[6] Huang Y. Innovation on road soft foundation treatment method of technical economy. Urban Roads Bridges \& Flood Control, Vol. 9, 2014, p. 105-109+18.

[7] Chen S. J. Subgrade construction technology of highway construction management on site and discussed. Transpo World, Vol. 9, 2015, p. 22-23.

[8] Gu L. J., Zhao W. J., Liu X. C. Low vacuum preloading patent technology application in the engineering construction. Water Resources Planning and Design, Vol. 4, 2009, p. $62-63$.

[9] Yuan Haiping, Han Zhiyong, Shi Xianzeng, et al. Application of dynamic compaction method in soft soil subgrade treatmentin Wanjiang Region. Construction Technology, Vol. 45, Issue 11, 2016, p. 50-54.

[10] Yuan Haiping, Li Weiqiang, Liu Mengxiu, et al. Simulation study on the optimization of the space between plastic drainage plate drains using vacuum preloading technology in soft foundation. Construction Technology, 2016, p. 58-62.

[11] Gu C. C., Zhang Y. T., Chen H. S. Test and analysis on reinforcement effect of high vacuum compaction method in soft soil. Research Publishing Services, Singapore, 2010, p. 755-761.

[12] Chang Dave Ta The, Lou Xiao Ming, Xu Si Long Innovative soft soil stabilization using simultaneous high-vacuum dewatering and dynamic compaction. Transportation Research Record, 2010, p. 138-146.

[13] Liang R. Y., Xu S. L. High vacuum densification method for soft soil improvement. GeoCongress, Vol. 225, 2012, p. 1928-1937.

[14] Li J. P., Ma Y., Yang P. F., et al. Analysis of strengthening effect of HVDM with SHVLPDM in Soft Soil foundation. Journal of Architecture and Civil Engineering, Vol. 28, Issue 2, 2011, p. 79-83.

[15] Huang X. Z. Low high vacuum layered secret preloading on soft foundation processing supervision control points and methods. Jiangxi Building Materials, Vol. 12, 2017, p. 177-178.

[16] Dubey R. S. Construction of a rigid pavement by vacuum dewatering method. Indian Concrete Journal, Vol. 71, Issue 1, 1997, p. 13-14.

[17] Li Y. H., Yang Y. H. Of powder-jetted pile construction technique in the application of highway soft soil subgrade. Technology and Market, 2018.

[18] Tian J. T. Powder spraying pile in soft soil subgrade engineering application. China Strategic Emerging Industry, 2018.

[19] Yang C. Powder Spray Pile Reinforcing Soft Soil Foundation of Applied Research. Wuhan University of Technology, 2014.

[20] Yan Q. Z., Cui L., Jiang L. Q. High vacuum tight method strengthening experimental study on the reclaimed soil foundation. China Engineering Structure Seismic Strengthening Transformation Technology Exchange Meeting, 2010.

[21] Xu S. L., Lou X. M. Practical example of High Vacuum Compacting Method consolidating dredge-fill fly ash foundation. Coal Ash China, Vol. 6, 2004, p. 19-21.
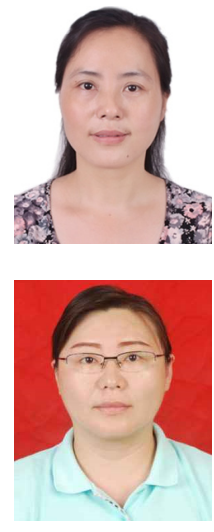

Liangrong Yuan received Bachelor degree in Jiangxi University of Science and Technology, Ganzhou, China, in 2000. Now she works as Associate Professor in Anhui Sanlian University. Her research interests include project budget and cost management.

Menglan Song received Master degree and currently working as Associate Professor in Anhui Sanlian University. Her research interests include project budget and cost management. 